The mediation between participative leadership and employee exploratory innovation: Examining intermediate knowledge mechanisms

\begin{tabular}{|r|l|}
\hline Journal: & Leadership \& Organization Development J ournal \\
\hline Manuscript ID & LODJ -07-2018-0245.R1 \\
\hline Manuscript Type: & Research Paper \\
\hline Keywords: & $\begin{array}{l}\text { participative leadership, employee exploratory innovation, Coworker } \\
\text { knowledge sharing, Employee absorptive capacity, Organizational } \\
\text { learning theory, multilevel evidence }\end{array}$ \\
\hline \multicolumn{2}{|l}{} \\
\hline
\end{tabular}




\title{
The mediation between participative leadership and employee exploratory
}

\section{innovation: Examining intermediate knowledge mechanisms}

\begin{abstract}
Purpose - This study examines the role of intermediate knowledge mechanisms on the participative leadership-employee exploratory innovation relationship using a distal mediation model.

Design/methodology/approach - Deploying a time-lagged questionnaire method implemented over four business quarters, data is generated from 1600 responses in R\&D units of Taiwanese technology firms.

Findings - The structural equation modeling results reveal that (1) participative leadership is positively related to employee exploratory innovation; (2) coworker knowledge and (3) absorptive capacity partially mediate the relationship between participative leadership and employee exploratory innovation independently; and, (4) coworker knowledge sharing in combination with absorptive capacity partially mediates this relationship.

Originality/value - The findings contribute new knowledge on the relationship between participative leadership and employee exploratory innovation by uncovering intermediate knowledge mechanisms that augment this relationship.
\end{abstract}


Keywords Participative leadership, Coworker knowledge sharing, Employee absorptive capacity, Employee exploratory innovation, Organizational learning theory, Emerging economy.

Paper type Research paper. 


\section{The mediation between participative leadership and employee exploratory}

\section{innovation: Examining intermediate knowledge mechanisms}

\section{Introduction}

Most leadership research to date has focused on exploring the relationship between transformational leadership and associated outcomes (Chen et al., 2012; Jansen et al., 2009; Kang et al., 2015; Li, Lin et al., 2015; Lin et al., 2016), or empowering leadership and associated outcomes (Amundsen and Martinsen, 2015; Hao et al., 2018; Kim and Beehr, 2017; Lam et al., 2012; Li, He et al., 2015; Lorinkova et al., 2013; Lorinkova and Perry, 2017). Also, previous research in participative management and organization innovation had indicated that participative management procedure is one of important way to get employee involved in improving organizational innovation (Monge et al., 1992). Participative management can use both formal and informal approaches to help improve organizational innovation performance such as creation of formal system for collecting promising innovations proposed by organizational employees (Monge and Cozzens, 1986). Organizations can also adopt project teams or R\&D Departments to facilitate innovation (Morton, 1971; Zaltman et al., 1973). In addition, organizations may efficiently search their environments for innovative means or products so that assure success (Kanter, 1988; Mohr, 1969; Tushman, 1977). Studies on employee driven innovation revealed that 
democratic dialogue as a conversation to share knowledge creation to let others participate your knowledge, to dare your own basic assumptions and those of others on willingness basis, and to care each other with respect despite various attitudes and interests (Kristiansen and Bloch-Poulsen, 2005). Consequently, dialogue can be realized as a special form of conversation with a unique quality (Stewart, 1999) that differentiates it from discussion or negotiation (Kristiansen and Bloch-Poulsen, 2010). Dialogue about work practices or other issues in a space as one of numerous drivers of employee driven innovation where it is key you discourse paradoxes and variances (Stewart et al., 2004; Baxter, 2006). Practice-based innovation refers to the interface and the interplay between explicit and implicit dimensions of work practices which can be sources for learning and innovation processes (Feldman, 2000; Feldman and Pentland, 2003). The underlying idea is that paradoxes and differences between work processes can be officially agreed (the explicit dimension) and perceived in practice (the implicit dimension) and thus creates potentials for learning and practice-based innovations in an organization (Ellström, 2010). Regarding explicit dimension of practice-based innovation, it focuses on how the explicit work process is reproduced and realized in actual practice. Accordingly, it covers activities that aim to implement and sustain the officially agreed work processes/tasks in practical action (Ellström, 2010). The driving forces for practice-based innovation are facing new possible crisis 
situation or turning point that organizational members start to challenge and become ready to change established patterns of thought and action (Barley and Tolbert, 1997). Rapid technical development, increased quality requirements, or changing demands from customers, colleagues or management (Lundvall and Nielsen, 1999).

The foundational assumption for this body of investigation is that leadership is a recognized source of competitive advantage (Clark and Waldron, 2016). There has, however, been less attention given to the relationship between participative leadership and outcomes such as innovation (e.g., Huang et al., 2006; Trevor-Roberts et al., 2003).

Exploratory innovation is defined by characteristics such as search, variation, flexibility, experimentation, and risk-taking (March, 1991). It has the potential to change institutionalized learning through researching and developing innovative technologies and new markets to adapt to environmental dynamism and competitiveness (Lubatkin et al., 2006). Exploratory innovation is, therefore, central to the performance of firms facing dynamic environments (Gibson and Birkinshaw, 2004; Lubatkin et al., 2006) and for their future growth (Wei et al., 2014). Yet, investigation of the role of participative leadership as an antecedent of exploratory innovation remains in its infancy (Jansen et al., 2006; Mom et al., 2009).

Participative leadership is defined as leadership that draws on member 
information and intelligence, reducing hierarchical barriers by involving individual organizational members in decision-making (Arnold et al., 2000). Though this approach has recently been linked to manager exploratory innovation (Jansen et al., 2006; Mom et al., 2009; Li, Lin et al., 2015; Mom et al., 2015; Rogan and Mors, 2014), how participative leadership can deliver employee exploratory innovation remains neglected and is an important knowledge void in the leadership literature. Since innovation is deemed an outcome of organizational learning (Andreeva and Kianto, 2011; Lane et al., 2006), we examine mediation effects of coworker knowledge sharing and absorptive capacity on the participative leadership-employee exploratory innovation relationship in R\&D units of Taiwanese technology firms. In doing so, this study contributes to the Organizational Learning Theory (OLT) and innovation research by explaining how firm-level leadership and the knowledge sharing and absorptive capacities of employees interact to shape employees' exploratory innovation application. The conceptual framework is shown in Figure 1.

Coworker knowledge sharing is defined as coworkers sharing task-relevant ideas, information, and suggestions with others (Kim and Yun, 2015; Srivastava et al., 2006); while absorptive capacity is defined as the ability to acquire external knowledge, assimilate it, and exploit it (Cohen and Levinthal, 1990). The argument is made that this capacity exists at the employee-level such that employees drive the 
organizational learning ability, consistent with Chang et al. (2012). Both of these knowledge mechanisms have been linked to participative leadership effectiveness and the achievement of firm-level outcomes. For instance, Huang et al. (2010) argue that coworker knowledge sharing is a mechanism for organizational learning processes between participative leadership and outcomes; Nambisan (2013) suggests that employees' absorptive capacity increases exploratory innovation under a participative approach, but highlight the need to examine how this relationship works; while, employee knowledge sharing is suggested to interact with employee absorptive capacity for innovation ends (Liao et al., 2007). Taken together, the roles played by these knowledge mechanisms form the basis of hypotheses development.

This paper is structured accordingly: first, the theory underpinning the conceptual framework is presented and the study hypotheses are outlined. Next, the research methodology is considered then data analysis is outlined. The study's results are presented and discussed with managerial implications drawn for leadership theory and practice.

\section{...Insert Figure 1 about here...}

\section{Theory and hypotheses development}


We begin by presenting the logic for a direct relationship between participative leadership and employee exploratory innovation. Next, drawing on the OLT, the hypotheses for the mediation effect of each intermediate mechanism in turn - coworker knowledge and absorptive capacity—are developed. Then, their joint mediation effect on the participative leadership-employee exploratory innovation relationship is presented.

Srivastava et al. (2006) contend that leader behavior stimulates an employee response. They find that empowering leadership is positively related to employee performance. This finding builds on the positive relationship between transformational leadership and outcomes, reported by Wang et al. (2005). With regard to innovation, Berson et al. (2006) suggest that leaders stimulate employee exploratory innovation by providing contextual support to develop their ideas. Similarly, Newman et al. (2016) argue that participative leaders promote employee involvement in decision-making processes by providing encouragement, support, and influence. It is through employee involvement in decision-making processes that participative leaders subsequently create the opportunities for employees' skill and career development (Miao et al., 2013), which in turn fosters employees' innovation efforts. This relationship is indirectly supported by Jansen et al. (2006) who contend that the higher the level of centralization in decision-making (i.e. lower employee 
participation), the lower the firm's level of exploratory innovation. In a similar vein but for managers, Mom et al. (2009) argue that decision-making authority is positively related to manager exploratory innovation. Extended to the employee level, then, reduced authority and autonomy to make decisions would weaken employee exploratory innovation. Since the contextual conditions created through participative leadership counter these impediments, this leadership approach is related to innovative work behavior (de Jong and den Hartog, 2010) as well as exploratory innovation more broadly (Jansen et al., 2009; Mom et al., 2009). Participative leadership, therefore, is expected to enhance employee exploratory innovation, but this relationship is expected to strengthen through coworker knowledge sharing and employee absorptive capacity.

\section{The roles of coworker knowledge sharing and employee absorptive capacity}

We focus on knowledge mechanisms that exist at the employee-level, in part to address the neglect of micro-level processes in the leadership - outcome relationship.

Wang and Noe (2010, p. 117) identify that:

'knowledge sharing refers to the provision of task information and know-how to help others and to collaborate with others to solve problems, develop new ideas, or implement policies or procedures...Knowledge sharing can occur via written 
correspondence or face-to-face communications through networking with other experts, or documenting, organizing and capturing knowledge for others.'

While coworker knowledge sharing is a micro-level process that occurs between individuals (Wang and Noe, 2010), absorptive capacity is often assumed to be an organizational-level construct (e.g. Cohen and Levinthal, 1989, 1990; Lane and Lubatkin, 1998; Lane et al., 2001; Van den Bosch et al., 1999), but it also exists at the micro-level as observed by Lane et al. (2006). Specifically, it is 'a function of the personal absorptive capacity of its members, as well as the structures and processes of the organizational subunits to which they belong. Understanding these relationships and interactions can shed new light on how a firm develops and uses its absorptive capacity' (Lane et al., 2006, p. 854 [emphasis added]).

The role of knowledge mechanisms at the employee-level in conjunction with the organizational-level leadership approach adopted highlights the multi-level interactions that might be taking place, but which remain overlooked in the investigation of leadership effectiveness. This neglect has been signaled in the knowledge sharing and absorptive capacity literatures. For instance, Wang and Noe (2010, p. 127) stress, 'more work using multilevel analysis is needed to appropriately examine knowledge sharing dynamics'; similarly, Martinkenaite and Breunig (2016, p. 701) contend that 'neglecting a multi-level construct of absorptive capacity limits 
the understanding of how learning and innovation processes emerge'.

Simon (1978) indicates that exploratory innovation originates from the process of knowledge sharing with others, but also the way in which information and knowledge is processed by individuals (Shiffrin and Schneider, 1977). Adhering to this logic, we suggest that participative leadership is more likely to influence employee exploratory behavior through the intermediate knowledge mechanisms of coworker knowledge sharing and employee absorptive capacity. These mechanisms reflect the two learning flow directions for converting individual learning into actual knowledge resources: feed-forward (knowledge sharing) and feed-back (absorptive capacity) (Vera and Crossan, 2004); both of which are positively related to exploratory innovation (Raisch and Birkinshaw, 2008). We now address the role of coworker knowledge sharing and employee absorptive capacity in turn.

First, we hypothesize that coworker knowledge sharing — sharing task-related knowledge with others - is an intermediate mechanism between participative leadership and employee exploratory innnovation. This is consistent with the finding of Srivastava et al. (2006) that knowledge sharing has a positive impact on the empowering leadership and performance relationship, and Lorinkova et al. (2013) who highlights the positive role of knowledge sharing behaviors for innovation more generally. Participative leaders encourage communication flows between employees 
and, as a result, knowledge sharing is generated creating knowledge at a collective level (Bartol and Srivastava, 2002). More specifically, participative leadership fosters knowledge sharing by establishing mutual trust, effective systems for communication, and shared organizational norms, such as an expectation of coworkers to engage with this process (Jo and Joo, 2011). This approach drives employees to research new technologies/procedures and/or develop new products/services/markets, i.e. demonstrate employee exploratory innovation. For instance, according to Wang and Noe (2010, p. 115) "knowledge sharing is the fundamental means through which employees can contribute to... innovation, and ultimately the competitive advantage of the organization". We suggest, therefore, that participative leadership will have a positive effect on employee exploratory innovation through coworker knowledge sharing. Thus:

H1. Coworker knowledge sharing mediates the relationship between participative leadership and employee exploratory innovation.

While absorptive capacity can reflect the firm's stocks of external knowledge (Cohen and Levinthal, 1990) it also comprises the collective knowledge of employee learnings (Chang et al., 2012). The latter builds on the view of absorptive capacity as 
knowledge sharing routines and emphasizes the role of organizational members in developing, deploying, and maintaining absorptive capacity (Lane et al., 2006). Participative leaders that involve employees in decision-making subsequently raise employees' perceptions and understanding of the business environment (Cohen and Levinthal, 1990), developing their absorptive capacity in turn (Jansen et al., 2005). This directionality is supported by Martinkenaite and Breunig (2016, p. 700) who contend that "governance mechanisms influence how employees interact with the external environment, how they communicate and integrate new knowledge". i.e. leadership driving employee absorptive capacity. Individuals can then rapidly acquire and assimilate their knowledge by independently selecting suitable knowledge stocks to transform and exploit during meetings and discussions (Nambisan, 2013). Tsai (2001), for example, observe that technical engineers are in possession of related knowledge that can be used to develop new ideas, products, or new markets through new technologies, resulting in exploratory innovation according to Cohen and Levinthal (1990). Similarly, Enkel et al. (2017) demonstrate that employees contribute to the realization of exploratory innovation through their ability to identify, assimilate, and utilize external knowledge; while Nambisan (2013) reports that exploratory innovation is achieved via the knowledge assimilation abilities of organizational members for increased risk-taking and experimentation. 
Participative leadership, then, is expected to encourage greater employee absorptive capacity by motivating employees to transform and exploit new external knowledge through increasing their participation in decision processes (e.g. inclusive meetings that embrace employee brain-storming, involvement, and input). In turn, this absorption and assimilation of knowledge enables exploratory innovation by employees. Hence:

H2. Absorptive capacity mediates the relationship between participative leadership and employee exploratory innovation.

Van den Bosch et al. (1999) contend that absorptive capacity is driven in part by the transfer of knowledge across and within subunits, where prior related knowledge is used to advance exploratory innovation (García-Morales et al., 2008). Drawing on the OLT, Lane et al. (2006, p. 848) explain how "increased learning in a particular area enhances the organization's knowledge base in that area, which further increases its absorptive capacity". Following this logic but applying it to the employee level, transfer of knowledge occurs through coworker knowledge sharing that increases collective knowledge and in turn develops employee absorptive capacity. This echo recent developments in the information systems field that extends the discussion of 
drivers of organizational absorptive capacity from formal knowledge processing, such as internal compensation practices and firm's organization structure (e.g. Lane and Lubatkin, 1998), toward employee absorptive capacity and the micro-level processes and mechanisms that serve as its antecedents.

For instance, Oliveira et al. (2015) indicate that knowledge sharing is likely to assist individuals' new external knowledge awareness, but then requires individuals to acquire, assimilate, transform, and exploit that new external knowledge (capacity to absorb new or at least new-to-the individual external information) for innovation ends. The inference here is that when a firm establishes a culture of knowledge sharing from a participative leadership approach, their employees' subsequently acquire new learning abilities such as absorptive capacity to process this knowledge (Liao et al., 2007). A sequential process in the intermediate knowledge mechanisms being investigated is, therefore, suggested here such that coworker knowledge sharing may precede and subsequently drive employee absorptive capacity for innovation ends. In other words, employee absorptive capacity mediates the path between employee knowledge sharing and innovation (e.g. Liao et al., 2007). Thus, both coworker knowledge sharing and absorptive capacity will act together as integrated mediating mechanisms between participative leadership and employee exploratory innovation. 
To summarize participative leaders build a supportive environment for employee participation through establishing shared learning norms that, in turn, facilitate coworker knowledge sharing, the first mediator in the sequence to employee exploratory innovation. This knowledge then requires employees' assimilation and transformation through absorptive capacity, which is the second necessary mediator in the sequence to increase employee exploratory innovation. Thus:

H3. Coworker knowledge sharing and absorptive capacity together mediate the relationship between participative leadership and employee exploratory innovation.

\section{Method \\ Sample and procedures}

Our research framework aimed to examine the intermediate knowledge mechanisms between participative leadership and employee exploratory innovation. To test our framework, we sent an invitation letter to Chief Executive Officers (CEOs) to participate in the study, randomly selected technology firms from the Taiwan Economic Journal (TEJ) database. We used personal contact to access these CEOs to accept our invitation. Technology sectors were chosen because these sectors typically 
contend with environmental dynamism and competitiveness across different markets and pursue exploratory innovation organization-wide (He and Wong, 2004). Technology-oriented firms also feature heavily in the industrial policy of emerging economies as a means to generate future industry growth and income (Hodgkinson et al., 2016). We distributed 1786 supervisor's and their direct subordinate's questionnaires in R\&D units from 79 firms in Taiwan. Sectors covered include: 39 high technology (49.4\%), 4 medium technology (5.0\%), and 36 low technology $(45.6 \%)$. Due to varying firm size in the sample, the samples varied in size from 6 to 80.

Data collection was conducted across 4 business quarters in 2016. We included a \$15 (U.S.) dollar incentivization to each participant and offered free consultancy services for each participant's firm. We conducted three rounds of reminders in each of the quarters. In quarter 1 , we sent surveys to the 1786 subordinates to rate their direct supervisor's participative leadership. We recycled 1745 valid subordinate's questionnaires (97.7\%) from 79 firms. In quarter 2, we once again sent surveys to the 1745 subordinates to rate their coworker knowledge sharing. We recycled 1701 valid subordinate's questionnaires (97.5\%) from 79 firms. In quarter 3, we sent surveys to 1701 supervisors within those same firms to rate their direct subordinate's absorptive capacity. We recycled 1652 valid supervisor's questionnaires (97.1\%) from 79 firms. 
In quarter 4, we again sent surveys to the 1652 supervisors to rate their direct subordinate's exploratory innovation. We finally acquired 1600 valid supervisor's questionnaires (89.6\%) from 79 firms. Data from the respondent firms ranged from 6 to 73 supervisor's and subordinate's samples. Each firm had on average 20.25 supervisor's and subordinate's samples $($ s.d. $=9.56)$. Supervisors were on average aged 41.48 (s.d. $=7.01$ ) and $29.3 \%$ were women; subordinates were on average aged 32.92 (s.d. $=6.16$ ) and $43.2 \%$ were female. CEO firm tenure was on average 7.38 years (s.d. = 9.08). For education level, supervisors with (1) Masters or above comprised 61.8\%, (2) Bachelor's degree comprised 34.9\%, (3) and Others comprised $3.3 \%$ of the sample; for subordinates, (1) Masters or above comprised $52.8 \%$, (2) Bachelor's degree comprised $41.8 \%$, and (3) Others comprised $5.4 \%$ of the respective sample. In assessing non-response bias, no significant differences were found between the first $10 \%$ of respondents and the last $10 \%$ of respondents for either the supervisor or subordinate samples.

To attempt to eliminate common method variance (CMV), we collected data on the independent variables and dependent variables from different respondents (subordinates and their direct supervisors). We followed the advice of Podsakoff et al. (2003) across survey administration: First, we collected data from multiple sources across four different time periods. Second, we used a Harman one-factor test to 
examine the CMV and we conducted an unrotated factor analysis. The results showed that five factors were obtained (so more than one factor); the variance explained by the first factor was $22.92 \%$ (so less than $50 \%$ ); and finally, the variance explained by the first factor was less than half of the total variance explained $(63.39 \%)$. Third, we also used a marker variable correlation procedure. Following Podsakoff et al. (2003), social desirability was used as the marker variable in the model and this variable is theoretically unrelated to any other variable in the model. The analysis revealed that social desirability was not correlated to the research variables $(p \geq .05)$, with no significant difference between the two models found. Collectively, we can conclude that CMV does not appear to be present in the data.

\section{Measures}

Measurement items were adapted and translated into Chinese by using the back-translation method (Brislin, 1980) and all items were assessed on a 5-point Likert scale. Please refer to Appendix for all measurement items.

Employee exploratory innovation. We adapted the 7-item measures of Mom et al. (2009) to assess employee exploratory innovation $(\alpha=.70)\left(\chi^{2} / d f=2.82, p>.05\right.$, RMSEA $=.03, \mathrm{CFI}=.99, \mathrm{GFI}=.99, \mathrm{TLI}=.99)$. In terms of adaptations, we changed the subject from managers to employees. 
Participative leadership. A 6-item measure by Arnold et al. (2000) was adopted to assess participative leadership $(\alpha=.70)\left(\chi^{2} / d f=5.32, p<.01\right.$, RMSEA $=.05$, CFI $=.99, \mathrm{GFI}=.99, \mathrm{TLI}=.99)$

Coworker knowledge sharing. Kim and Yun's (2015) 7-item measure was adopted to assess coworker knowledge sharing $(\alpha=.89)\left(\chi^{2} / d f=14.78, p<.01, \mathrm{RMSEA}=.08\right.$, $\mathrm{CFI}=.98, \mathrm{GFI}=.96, \mathrm{TLI}=.97)$.

Absorptive capacity. The 6-item measure of Chang et al. (2012) was adopted to assess absorptive capacity $(\alpha=.86)\left(\chi^{2} / d f=13.81, p<.01\right.$, RMSEA $=.08$, CFI $=.98$, GFI $=.98, \mathrm{TLI}=.97)$.

\section{Control variables}

We included various items as control variables that may be related to employee exploratory innovation. First, we controlled for specific firm-level variables: (1) firm size and firm age (He and Wong, 2004; Ozer and Zhang, 2015); (2) unit size and unit age (Jansen et al., 2006); (3) technology sector (He and Wong, 2004); (4) top management team (TMT) size (Beckman, 2006); and, (5) CEO tenure (Cao et al., 2010; Jansen et al., 2009). Second, we also controlled for specific employee-level variables: (1) age (Mom et al., 2015; Rogan and Mors, 2014), (2) firm tenure (years) (Mom et al., 2015), (3) unit tenure (years) (Mom et al., 2015), and (4) education level 
(Mom et al., 2015). Third, we controlled for environmental dynamism and environmental competitiveness (Jansen et al., 2006; Mom et al., 2009). Finally, we used social desirability as the marker variable (as discussed above).

Environmental dynamism. A 5-item measure by Jansen et al. (2006) was adopted to assess environmental dynamism $(\alpha=.76)\left(\chi^{2} / d f=5.65, p<.01\right.$, RMSEA $=.05$, CFI $=.99, \mathrm{GFI}=.99, \mathrm{TLI}=.99)$.

Environmental competitiveness. A 4-item measure by Jansen et al. (2006) was adopted to assess environmental competitiveness $(\alpha=.70)\left(\chi^{2} / \mathrm{df}=8.15, p<.001\right.$, RMSEA $=.07$, CFI $=.99$, GFI $=.99$, TLI $=.98)$.

Social desirability response. A 5-item measure by Hays et al. (1989) was adopted to assess socially desirability $(\alpha=.95)\left(\chi^{2} / \mathrm{df}=3.58, p<.05, \mathrm{RMSEA}=.04, \mathrm{CFI}=.99\right.$, $\mathrm{GFI}=.99, \mathrm{TLI}=.99)$.

\section{Results}

Table I shows the descriptive statistics and correlations. No correlation coefficients exceed .65 , which is indicative of a lack of multicollinearity among these variables (Cao et al., 2009; Tabachnick and Fidell, 1996). We also conducted a series of indicators of multicollinearity tests among these variables, including tolerance (criteria: 0 1), variance inflation factor $(\mathrm{VIF})($ criteria $\leq 10)$ and condition index 
(criteria < 30) (Tabachnick and Fidell, 1996). All indicators met with criteria

(tolerance $=.28 \sim .47, \mathrm{VIF}=2.11 \sim 3.61$ and condition index $=28.78)$.

\section{...Insert Table I about here...}

\section{Testing the measurement model}

In order to confirm the construct-related discriminant validity, we examined whether these four measures were different constructs rather than one single construct (Anderson and Gerbing, 1988; Bagozzi et al., 1991). The four-factor baseline model (i.e., employee exploratory innovation; participative leadership; coworker knowledge sharing; absorptive capacity) was compared to 11 alternative models. Table II shows a comparison of the measurement models. Results reveal that the baseline model has the best model fit in comparison to the other models.

\section{...Insert Table II about here...}

Analytical strategy

He and Wong (2004) indicate that sector (including high technology; medium technology; low technology) is related to employee exploratory innovation. Additionally, Mom et al. (2015) also claim that education level (including masters or above; bachelor; 'other') is related to employee exploratory innovation. Following the 
rules of dummy variables in the model, the categorical variables for sector and education were transformed into two dummy variables, respectively (high technology, low technology; master above, bachelor). Firm size was transformed into the natural log values (Cao et al., 2009).

All data analysis was undertaken following the recommendations of James et al. (2006) and employed Mplus 7.4 to conduct structural equation modeling (SEM) with estimated confidential interval (CI) by normal distribution and Monte Carlo simulation. The SEM method benefits to estimate every effect of paths (James et al., 2006). In order to meet our theoretical hypotheses, our framework was considered as a partial mediating model (James et al., 2006). The Mplus software provides the normal distribution and Monte Carlo simulation (Muthén and Muthén, 2015) to examine the confidence intervals (CIs). Monte Carlo simulation would avoid the bias of parameters estimates to apply roubust testing the CIs because data may present skew of the distributions this method (Preacher et al., 2010). The results of Monte Carlo simulation were a robust check of our model. Due to the manager-employee data were nested in each firm, we chose a multilevel SEM (MSEM) analysis to correctly interpret the results. For instance, firm-related variables (i.e., firm size, firm age, TMTs, high technology, low technology, and CEOs tenure) were taken as the firm-level, and other variables were taken as at the individual-level. 


\section{Hypothesis testing}

The results of the normal distribution are presented in Table III. The robustness results of Monte Carlo simulation are shown in Table IV.

\section{...Insert Table III and Table IV about here...}

Following James et al. (2006), three conditions of partial mediation effects need to exist. First, the parameter of direct effect is significant. Second, all parameters of indirect paths are significant. Finally, these parameters of indirect effects are significant.

Hypothesis 1 proposed that coworker knowledge sharing mediates the relationship between participative leadership and employee exploratory innovation. The results reveal that coworker knowledge sharing does significantly mediate the relationship between participative leadership and employee exploratory innovation $(b$ $=.12, p<.01 ; 95 \% \mathrm{CI}$ as a normal distribution: $.05, .19 ; 95 \% \mathrm{CI}$ as Monte Carlo simulation: .05, .21), providing full support for hypothesis 1 .

Hypothesis 2 expected that absorptive capacity would mediate the relationship between participative leadership and employee exploratory innovation. The results reveal that absorptive capacity significantly mediates the relationship between participative leadership and employee exploratory innovation $(b=.05, p<.05 ; 95 \%$ 
CI as a normal distribution: .02,.08; 95\% CI as Monte Carlo simulation: .02, .09), and again, full support is found.

Finally, hypothesis 3 posited that coworker knowledge sharing and absorptive capacity together mediate the relationship between participative leadership and employee exploratory innovation. The results reveal that coworker knowledge sharing and absorptive capacity significantly mediate the relationship between participative leadership and employee exploratory innovation $(b=.04, p<.05 ; 95 \% \mathrm{CI}$ as a normal distribution: .01, .07; 95\% CI as Monte Carlo simulation: .01, .08), providing support for this hypothesis.

\section{Discussion}

Drawing on the OLT, this study sought to investigate the nature of the relationship between participative leadership and employee exploratory innovation in R\&D units of Taiwanese technology firms. Specifically, the concern of this study was the role of intermediate knowledge mechanisms in explaining the participative leadershipemployee exploratory innovation path.

Until now, the role of intermediate mechanisms and how they feature in this relationship has been neglected in the leadership literature, which has focused predominantly on the direct participative leadership-manager exploratory innovation 
relationship (Jansen et al., 2006; Mom et al., 2009; Li, Lin et al., 2015; Mom et al., 2015; Rogan and Mors, 2014). Yet, employees are frequently the source of innovation or executors of the innovation process within organizations. Therefore, we sought to understand how firms and managers can leverage participative leadership for this end through those knowledge mechanisms that exist at the employee-level. The findings establish some insights of participative leadership for employee exploratory innovation. Further, employee coworker knowledge sharing and employee absorptive capacity, both independently and in combination, are observed to be necessary intermediate knowledge mechanisms between participative leadership and employee innovation.

\section{Theoretical implications}

The results extend previous research on participative leadership and innovation by demonstrating that participative leadership is related to employee exploratory innovation (Lee and Meyer-Doyle, 2017; Mom et al., 2009). The finding of a positive relationship here extends the empirical results of de Jong and den Hartog (2010), de Poel et al. (2012), Jansen et al. (2006), Mom et al. (2009), and Newman et al. (2016) from the manager-level to the employee-level. However, the inclusion of intermediate knowledge mechanisms in our analysis reveals that while participative leadership can 
directly affect employee innovative behavior as expected, there are clear additional indirect mediation effects from coworker knowledge sharing and employee absorptive capacity. Specifically, the results confirm that participative leadership is related to employee exploratory innovation through coworker knowledge sharing. Wang and Noe (2010) theorize that leadership characteristics may affect the level of knowledge sharing through creating knowledge sharing norms. The finding of a positive mediation effect sheds much needed light on this interaction by specifically linking participative leadership and its characteristics to individual knowledge sharing activity and employee exploratory innovation in turn. This finding directly addresses the call by Huang et al. (2010) for greater understanding of the impact of participative leadership, by demonstrating its multi-level interaction with coworker knowledge sharing for employees' radical innovation. The finding of a positive mediation effect also generates meaning of participative management and organization, employee driven innovation, and practice-based innovation. Specifically, previous on participative management innovation and organization, employee driven innovation and practice-based innovation mainly focused on drivers and consequences of such participative management and organization as well as employee driven innovation. This study contributes to the field of participative management and innovation in general by revealing the intermediation linkages as the call for previous studies (e.g., 
Ellström, 2010; Monge et al., 1992; Feldman and Pentland, 2003). In other words, this study indicated that organizations can use participative leadership through different paths such as coworker knowledge sharing and absorptive capacity to promote employee exploratory innovation. In line with previous studies (e.g., Cohen and Levinthal, 1990; Chang et al., 2012; Jansen et al., 2005; Minbaeva et al., 2003), knowledge transfer/sharing and absorptive capacity can serve vital mechanisms to facilitative employee exploratory innovation and organizational performance.

Results also confirm that participative leadership drives employee exploratory innovation through employee absorptive capacity. This reinforces the need highlighted by Lane et al. (2006) to investigate the role of absorptive capacity at the individual-level. Since extant absorptive capacity studies have positioned their analysis at the organizational-level, the contribution of absorptive capacity as displayed by individual organizational members has been neglected. Yet, the finding here clearly demonstrates that this learning ability at the micro-level enables participative leaders to drive employee exploratory innovation. The multi-level interactions observed demonstrate how learning processes and innovation emerge at the employee-level, which has been lacking both in the application of OLT constructs (Martinkenaite and Breunig, 2016; Wang and Noe, 2010) and in the leadership literature. 
Collectively, while participative leadership is important for employee exploratory innovation it is the knowledge mechanisms existing and interacting at the employee-level that are central to generating increased employee exploratory innovation from this leadership approach. Rather than emphasizing the positive role of sources of external advice for leaders (e.g. van Doorn et al., 2017), based on the findings we contend that employee-level knowledge mechanisms internal to the firm augment the positive participative leadership effect. Future research should consider such multi-level reasoning for further theoretical development of the leadershipinnovation relationship. We also reveal a serial mediation aspect here consistent with theoretical extensions derived from the OLT, i.e. the relationship between knowledge creation and knowledge use process as the micro-level (Lane et al., 2006). Specifically, knowledge sharing is a significant precursor to absorptive capacity and both mechanisms in conjunction act as an enabler of employee exploratory innovation outcomes, from participative leadership. This finding highlights a sequential and joint relationship in their mediation effects. Thus, participative leadership promotes employee exploratory innovation through both the feed-forward and the feed-back of knowledge flows, as proposed by Vera and Crossan (2004). While barriers to knowledge diffusion and use within firms are exacerbated by structural hierarchy, i.e. where detachment between leaders, managers, and employees exist (Reitzig and 
Maciejovsky, 2015), our finding here demonstrates that participative leadership circumvents these barriers. Specifically, it nurtures the micro-level coworker knowledge sharing and employee absorptive capacity that are necessary for greater employee exploratory innovation.

Beyond the findings here, there is an opportunity to further integrate leadership and learning theories into a single lens to illuminate the intermediate knowledge mechanisms involved in the generation of employee innovation outcomes across different leadership styles, such as transformational, empowering approaches, or knowledge governance (Ali et al., 2018). This highlights the need for leadership theory to integrate the OLT in future investigation of the innovation legacies of leadership across organizational levels to capture the complexities of leaderemployee relationships.

\section{Practical implications}

This study carries a number of practical implications for technology firms in Taiwan and other similar emerging economies. First, we encourage leaders to adopt a participative leadership approach since this drives employee involvement in organizational decision-making and fosters opportunities for coworker knowledge sharing. In doing so, managers and leaders will nurture employee exploratory 
innovation from their participative leadership approach. Second, we also recommend that participative leaders increase discussion in meetings and seek to stimulate employees' brainstorming and their contributions to decision-making to enhance employees' absorptive capacity. Here, employees need access to information and to be given roles in not only acquiring information and knowledge, but also be granted the opportunities to assimilate and use new knowledge for exploratory innovation ends independently, i.e. employees need autonomy and authority to draw on their absorptive capacity. Third, organizations should use more participative management methods such joint decision making, coworker support to share the knowledge and create a space to dialogue the potential innovation and barriers. More participative management methods such as learning in project groups (McGrath, 2001), providing more autonomy to individuals or groups in performing a task to develop exploratory innovation. Also, more participative management methods such as collectively redefining problems and collectively handling problems are vital to promote exploratory innovation in organizations (e.g., Campbell, 1960; Zollo and Winter, 2002). Finally, while developing these distinct intermediate knowledge mechanisms separately will enhance the participative leadership-employee exploratory innovation relationship, there are additional benefits to be gained from developing coworker knowledge sharing and employee absorptive capacity simultaneously. These 
mechanisms are not mutually exclusive, but rather there is a sequential relationship between these mechanisms, such that coworker knowledge sharing generates new-to-the-individual knowledge which then requires employee absorptive capacity to transform this knowledge for employee innovation ends. In developing both, firms and their managers ought to experience tangible benefits and improvements to employee exploratory innovation from a participative leadership approach.

\section{Limitations and future research directions}

We acknowledge a number of limitations to this study. First, since we focus specifically on technology firms in Taiwan we cannot conclude if these findings will generalize beyond the emerging economy context. Second, the study examines individual-level mediation effects and, thus, the inclusion of boundary conditions of related variables such as organizational culture and team-level variables was beyond the scope of this investigation, but should be explored. For instance, future research should explore possible cross-level effects, as per calls from authors such as Berson et al. (2006), Martinkenaite and Breunig (2016), and Wang and Noe (2010). Third, the study draws on the OLT as a theoretical lens to develop an integrative model of the intermediate knowledge mechanisms that influence the participative leadershipemployee exploratory innovation relationship. There are of course other theoretical 
lenses that could contribute further to our understanding of the causal mechanisms between leadership and employee innovation. For instance, theories of motivation, citizenship, or entrepreneurship may well offer significant insights here. As such, future research may draw on different theories or views to shed further light on the intermediate links, three-way boundary conditions, or mediated moderation relationships between leadership and innovation. Finally, the study adopted a time-lagged data collection method but, ultimately, the data is cross-sectional despite its dyadic nature. Future research should extend this research effort through a longitudinal investigation of dyad relationships.

\section{Conclusion}

Knowledge on the relationship between participative leadership and employee innovation outcomes remains in its infancy. The majority of extant leadership studies focus on other forms of leadership and their impact on macro-level outcomes rather than micro-level outcomes, such as the role of transformational leadership for unit innovation, corporate entrepreneurship (Chang et al., 2017) or performance (Chang et al., 2018). Those studies that have sought to address this weakness have established that participative leadership is related to manager exploratory innovation (e.g., Jansen et al., 2006; Mom et al., 2009; Mom et al., 2015; Li, Lin et al., 2015; Rogan and 
Mors, 2014), but its relationship with employee exploratory innovation is not clear.

This knowledge void is addressed here in the context of Taiwanese technology firms.

The findings clearly demonstrate that while participative leadership is indeed important to realizing employee exploratory innovation there exist key intermediate knowledge mechanisms that carry significant mediation effects both independently and jointly. Specifically, the findings demonstrate that coworker knowledge sharing and employee absorptive capacity are fundamental for firms to realize enhanced employee exploratory innovation from participative leadership, both independently and in their joint effect which strengthens this relationship further. The study calls for the integration of leadership and the OLT to explore further the multi-level knowledge dynamics at play for leadership effectiveness.

\section{References}

Ali, I., Musawir, A.U. and Ali, M. (2018), "Impact of knowledge sharing and absorptive capacity on project performance: the moderating role of social processes", Journal of Knowledge Management, Vol. 22 No. 2, pp. 453-477.

Amundsen, S. and Martinsen, Ø.L. (2015), “Linking empowering leadership to job satisfaction, work effort, and creativity", Journal of Leadership and Organizational Studies, Vol. 22 No.3, pp. 304-323. 
Anderson, J.C. and Gerbing, D.W. (1988), "Structural equation modeling in practice: a review and recommended two-step approach", Psychological Bulletin, Vol. 103 No. 3, pp. 411-423.

Andreeva, T. and Kianto, A. (2011), “Knowledge processes, knowledge-intensity and innovation: a moderated mediation analysis", Journal of Knowledge Management, Vol. 15 No. 6, pp. 1016-1034.

Arnold, J.A., Arad, S., Rhoades, J.A. and Drasgow, F. (2000), “The empowering leadership questionnaire: the construction and validation of a new scale for measuring leader behaviors", Journal of Organizational Behavior, Vol. 21 No. 3, pp. 249-269.

Bagozzi, R.P., Yi, Y. and Phillips, L.W. (1991), “Assessing construct validity in organizational research", Administrative Science Quarterly, Vol. 36 No. 3, pp. $421-458$.

Barley, S.R. and Tolbert, P.S. (1997), “Institutionalization and structuration: studying the links between action and institution", Organization Studies, Vol. 18 No. 1, pp. 93-117.

Bartol, K.M. and Srivastava, A. (2002), "Encouraging knowledge sharing: the role of organizational reward systems", Journal of Leadership \& Organizational Studies, Vol. 9 No. 1, pp. 64-76. 
Baxter, L.A. (2006), “Communication as dialogue”, in Shepherd, G.J., John, J.St. and Striphas, T. (eds.), Communication as...: Perspectives on Theory, Sage, Thousand Oaks, CA, pp. 101-109.

Beckman, C.M. (2006), “The influence of founding team company affiliations on firm behavior", Academy of Management Journal, Vol. 49 No. 4, pp. 741-758.

Berson, Y., Nemanich, L.A., Waldman, D.A., Galvin, B.M. and Keller, R.T. (2006), "Leadership and organizational learning: a multiple levels perspective", The Leadership Quarterly, Vol. 17 No. 6, pp. 577-594.

Brislin, R.W. (1980), “Translation and content analysis of oral and written materials", in Triandis, H.C. and Berry, J.W. (Eds.), Handbook of Cross-Cultural Psychology, Vol. 2, Allyn \& Bacon, Boston, MA, pp. 389-444.

Campbell, D.T. (1960), "Blind variation and selective retention in creative thought as in other knowledge processes", Psychological Review, Vol. 67 No. 6, pp. $380-400$.

Cao, Q., Gedajlovic, E. and Zhang, H. (2009), "Unpacking organizational ambidexterity: dimensions, contingencies, and synergistic effects", Organization Science, Vol. 20 No. 4, pp. 781-796.

Cao, Q., Simsek, Z. and Zhang, H. (2010), "Modelling the joint impact of the CEO and the TMT on organizational ambidexterity", Journal of Management Studies, 
Vol. 47 No. 7, pp. 1272-1296.

Chang, Y.-Y., Chang, C.-Y. and Chen, C.-W. (2017), “Transformational leadership and corporate entrepreneurship: cross-level mediation moderation evidence", Leadership \& Organization Development Journal, Vol. 38 No. 6, pp. 812-833.

Chang, Y.-Y., Chao, W.-C., Chang, C.-Y. and Chi, H.-R. (2018), “Transformational leadership influence on unit performance: cross-level moderated mediation evidence", Leadership \& Organization Development Journal, Vol. 39 No. 4, pp. $554-571$.

Chang, Y.-Y., Gong, Y. and Peng, M.W. (2012), "Expatriate knowledge transfer, subsidiary absorptive capacity, and subsidiary performance", Academy of Management Journal, Vol. 55 No. 4, pp. 927-948.

Chen, M.Y.-C., Lin, C.Y.-Y., Lin, H.-E. and McDonough, E.F. (2012), "Does transformational leadership facilitate technological innovation? The moderating roles of innovative culture and incentive compensation", Asia Pacific Journal of Management, Vol. 29 No. 2, pp. 239-264.

Clark, K.D. and Waldron, T. (2016), "Predictors of leadership behavior in early career white-collar professionals", Journal of Leadership \& Organizational Studies, Vol. 23 No. 1, pp. 27-38.

Cohen, W.M. and Levinthal, D.A. (1989), "Innovation and leaming: the two faces of 
R\&D”, Economic Joumal, Vol. 99 No. 397, pp. 569-596.

Cohen, W.M. and Levinthal, D.A. (1990), “Absorptive capacity: a new perspective on learning and innovation", Administrative Science Quarterly, Vol. 35 No. 1, pp. $128-152$.

de Jong, J. and den Hartog, D. (2010), "Measuring innovative work behaviour", Creativity \& Innovation Management, Vol. 19 No. 1, pp. 23-36.

de Poel, F.M., Stoker, J.I. and van der Zee, K.I. (2012), "Climate control? The relationship between leadership, climate for change, and work outcomes", The International Journal of Human Resource Management, Vol. 23 No. 4, pp. 694-713.

Ellström, P.-E. (2010), “Practice-based innovations: a learning perspective”, Journal of Workplace Learning, Vol. 22 No. 1/2, pp. 27-40.

Enkel, E., Heil, S., Hengstler, M. and Wirth, H. (2017), "Exploratory and exploitative innovation: to what extent do the dimensions of individual level absorptive capacity contribute?" Technovation, Vol. 60-61, pp. 29-38.

Feldman, M.S. (2000), “Organizational routines as a source of continuous change”, Organization Science, Vol. 11 No. 6, pp. 611-629.

Feldman, M.S. and Pentland, B.T. (2003), "Reconceptualizing organizational routines as a source of flexibility and change", Administrative Science Quarterly, Vol. 48 
No. 1, pp. 94-118.

García-Morales, V.J., Lloréns-Montes, F.J. and Verdú-Jover, A.J. (2008), “The effects of transformational leadership on organizational performance through knowledge and innovation", British Journal of Management, Vol. 19 No. 4, pp. 299-319.

Gibson, C.B. and Birkinshaw, J. (2004), "The antecedents, consequences, and mediating role of organizational ambidexterity", Academy of Management Journal, Vol. 47 No. 2, pp. 209-226.

Hao, P., He, W. and Long, L.-R. (2018), “Why and when empowering leadership has different effects on employee work performance: the pivotal roles of passion for work and role breadth self-efficacy", Journal of Leadership \& Organizational Studies, Vol. 25 No. 1, pp. 85-100.

Hays, R.D., Hayashi, T. and Stewart, A.L. (1989), “A five-item measure of socially desirable response set", Educational and Psychological Measurement, Vol. 49 No. 3, pp. 629-636.

He, Z. and Wong, P. (2004), "Exploration vs. exploitation: an empirical test of the ambidexterity hypothesis”, Organization Science, Vol. 15 No. 4, pp. 481-494.

Hodgkinson, I.R., Hughes, P. and Arshad, D. (2016), “Strategy development: driving improvisation in Malaysia", Journal of World Business, Vol. 51 No. 3, pp. 379-390. 
Huang, X., Iun, J., Liu, A. and Gong, Y. (2010), "Does participative leadership enhance work performance by inducing empowerment or trust? The differential effects on managerial and non-managerial subordinates", Journal of Organizational Behavior, Vol. 31 No. 1, pp. 122-143.

Huang, X., Shi, K., Zhang, Z. and Cheung, Y. L. (2006), “The impact of participative leadership behavior on psychological empowerment and organizational commitment in Chinese state-owned enterprises: the moderating role of organizational tenure", Asia Pacific Journal of Management, Vol. 23 No. 3, pp. $345-367$.

James, L.R., Mulaik, S.A. and Brett, J.M. (2006), "A tale of two methods", Organizational Research Methods, Vol. 9 No. 2, pp. 233-244.

Jansen, J.J.P., Tempelaar, M.P., van den Bosch, F.A.J. and Volberda, H.W. (2009), "Structural differentiation and ambidexterity: the mediating role of integration mechanisms", Organization Science, Vol. 20 No. 4, pp. 797-811.

Jansen, J.J.P., van den Bosch, F.A. J. and Volberda, H.W. (2006), "Exploratory innovation, exploitative innovation, and performance: effects of organizational antecedents and environmental moderators", Management Science, Vol. 52 No. 11, pp. 1661-1674.

Jansen, J.J.P., van den Bosch, F.A.J. and Volberda, H.W. (2005), "Managing potential 
and realized absorptive capacity: how do organizational antecedents matter?", Academy of Management Journal, Vol. 48 No. 6, pp. 999-1015.

Jansen, J.J.P., Vera, D. and Crossan, M. (2009), "Strategic leadership for exploration and exploitation: the moderating role of environmental dynamism", The Leadership Quarterly, Vol. 20 No. 1, pp. 5-18.

Jo, S.J. and Joo, B.K. (2011), "Knowledge sharing: the influences of learning organization culture, organizational commitment, and organizational citizenship behaviors", Journal of Leadership \& Organizational Studies, Vol. 18 No. 3, pp. 353-364.

Kang, J.H., Solomon, G.T. and Choi, D.Y. (2015), “CEOs' leadership styles and managers' innovative behaviour: investigation of intervening effects in an entrepreneurial context", Journal of Management Studies, Vol. 52 No. 4, pp. $531-554$

Kanter, R.M. (1988), "When a thousand flowers bloom : structural, collective, and social conditions for innovation in organization", in Staw, B.M. and Cummings, L.L. (Eds.), Research in Organizational Behavior, Vol. 10, JAI Press, Greenwich, CT, pp. 169-211.

Kim, M. and Beehr, T.A. (2017), "Self-efficacy and psychological ownership mediate the effects of empowering leadership on both good and bad employee 
behaviors", Journal of Leadership \& Organizational Studies, Vol. 24 No. 4, pp. 466-478.

Kim, S.L. and Yun, S. (2015), "The effect of coworker knowledge sharing on performance and its boundary conditions: an interactional perspective", Journal of Applied Psychology, Vol. 100 No. 2, pp. 575-582.

Kristiansen, M. and Bloch-Poulsen, J. (2005), Midwifery and Dialogue in Organizations: Emergent, Mutual Involvement in Action Research, Rainer Hampp Verlag, München, Deutschland.

Kristiansen, M. and Bloch-Poulsen, J. (2010), "Employee driven innovation in team (EDIT) - Innovative potential, dialogue, and dissensus", International Journal of Action Research, Vol. 6 No. 2/3, pp. 155-195.

Lam, L.W., Huang, X. and Lau, D.C. (2012), “Leadership research in Asia: taking the road less traveled?", Asia Pacific Journal of Management, Vol. 29 No. 2, pp. 195-204.

Lane, P.J. and Lubatkin, M. (1998), "Relative absorptive capacity and interorganizational learning”, Strategic Management Journal, Vol. 19 No. 5, pp. 461-477.

Lane, P.J., Koka, B.R. and Pathak, S. (2006), “The reification of absorptive capacity: a critical review and rejuvenation of the construct", Academy of Management 
Review, Vol. 31 No. 4, pp. 833-863.

Lane, P.J., Salk, J.E. and Lyles, M.A. (2001), “Absorptive capacity, learning, and performance in international joint ventures", Strategic Management Journal, Vol. 22 No. 12, pp. 1139-1161.

Lee, S. and Meyer-Doyle, P. (2017), "How performance incentives shape individual exploration and exploitation: evidence from microdata”, Organization Science, Vol. 28 No. 1, pp. 19-38.

Li, C.-R., Lin, C.-J. and Tien, Y.-H. (2015), “CEO transformational leadership and top manager ambidexterity", Leadership \& Organization Development Journal, Vol. 36 No. 8, pp. 927-954.

Li, M. and Zhang, P. (2016), "Stimulating learning by empowering leadership: can we achieve cross-level creativity simultaneously?", Leadership \& Organization Development Journal, Vol. 37 No. 8, pp. 1168-1186.

Li, S.-L., He, W., Yam, K.C. and Long, L.-R. (2015), “When and why empowering leadership increases followers' taking charge: a multilevel examination in China", Asia Pacific Journal of Management, Vol. 32 No. 3, pp. 645-670.

Liao, S.-h., Fei, W.-C. and Chen, C.-C. (2007), "Knowledge sharing, absorptive capacity, and innovation capability: an empirical study of Taiwan's knowledge-intensive industries", Journal of Information Science, Vol. 33 No. 3, 
pp. 340-359.

Lin, H.-C., Dang, T.T. H. and Liu, Y.-S. (2016), “CEO transformational leadership and firm performance: a moderated mediation model of TMT trust climate and environmental dynamism", Asia Pacific Journal of Management, Vol. 33 No. 4, pp. $981-1008$.

Lorinkova, N.M. and Perry, S.J. (2017), "When is empowerment effective? The role of leader-leader exchange in empowering leadership, cynicism, and time theft", Journal of Management, Vol. 43 No. 5, pp. 1631-1654.

Lorinkova, N.M., Pearsall, M.J. and Sims Jr., H.P. (2013), “Examining the differential longitudinal performance of directive versus empowering leadership in teams", Academy of Management Journal, Vol. 56 No. 2, pp. 573-596.

Lubatkin, M.H., Simsek, Z., Ling, Y. and Veiga, J.F. (2006), “Ambidexterity and performance in small- to medium-sized firms: the pivotal role of top management team behavioral integration", Journal of Management, Vol. 32 No. 5, pp. 646-672.

Lundvall, B.-A. and Nielsen, P. (1999), "Competition and transformation in the learning economy - illustrated by the Danish case", Revue d'Economie Industrielle, Vol. 88, pp. 67-90.

March, J.G. (1991), "Exploration and exploitation in organizational learning", 
Organization Science, Vol. 2 No. 1, pp. 71-87.

Martinkenaite, I. and Breunig, K.J. (2016), “The emergence of absorptive capacity through micro-macro level interactions", Journal of Business Research, Vol. 69 No. 2, pp. 700-708.

McGrath, R.G. (2001), "Exploratory learning, innovative capacity, and managerial oversight", Academy of Management Journal, Vol. 44 No. 1, pp. 118-131.

Miao, Q., Newman, A., Schwarz, G. and Xu, L. (2013), "Participative leadership and the organizational commitment of civil servants in China: the mediating effects of trust in supervisor", British Journal of Management, Vol. 24 No. S1, pp. S76-S92.

Minbaeva, D., Pedersen, T., Bjorkman, I., Fey, C.F. and Park, H.J. (2003), "MNC knowledge transfer, subsidiary absorptive capacity, and HRM", Journal of International Business Studies, Vol. 34 No. 6, pp. 586-599.

Mohr, L.B. (1969), "Determinants of innovation in organizations", American Political Science Review, Vol. 63 No. 1, pp. 111-126.

Mom, T.J.M., Fourné, S.P.L. and Jansen, J.J.P. (2015), “Managers' work experience, ambidexterity, and performance: the contingency role of the work context", Human Resource Management, Vol. 54 No. S1, pp. S133-S153.

Mom, T.J.M., van den Bosch, F.A.J. and Volberda, H.W. (2009), "Understanding 
variation in managers' ambidexterity: investigating direct and interaction effects of formal structural and personal coordination mechanisms", Organization Science, Vol. 20 No. 4, pp. 812-828.

Monge, P.R. and Cozzens, M.D. (1986), "Innovation through participatory management: the case for the Scanlon process", in Gray, D., Solomon T. and Hetzner W.H. (Eds.), Strategies and Practices for Technological Innovation, Elsevier, Amsterdam, Netherlands, pp. 319-329.

Monge, P.R., Cozzens, M.D. and Contractor, N.S. (1992), "Communication and motivational predictors of the dynamics of organizational innovation", Organization Science, Vol. 3 No. 2, pp. 250-274

Morton, J.A. (1971), Organizing for Innovation, McGraw-Hill, New York, NY.

Muthén, L.K. and Muthén, B.O. (2015), Mplus: Statistical Analysis with Latent Variables: User's Guide, 7th ed., Muthén \& Muthén, Los Angeles, CA.

Nambisan, S. (2013), "Industry technical committees, technological distance, and innovation performance", Research Policy, Vol. 42 No. 4, pp. 928-940.

Newman, A., Rose, P.S. and Teo, S.T.T. (2016), “The role of participative leadership and trust-based mechanisms in eliciting intern performance: evidence from China", Human Resource Management, Vol. 55 No. 1, pp. 53-67.

Oliveira, M., Curado, C.M.M., Maçada, A.C.G. and Nodari, F. (2015), "Using 
alternative scales to measure knowledge sharing behavior: are there any differences?", Computers in Human Behavior, Vol. 44, pp. 132-140.

Ozer, M. and Zhang, W. (2015), "The effects of geographic and network ties on exploitative and exploratory product innovation", Strategic Management Journal, Vol. 36 No. 7, pp. 1105-1114.

Podsakoff, P.M., MacKenzie, S.B., Lee, J.-Y. and Podsakoff, N.P. (2003), “Common method biases in behavioral research: a critical review of the literature and recommended remedies", Journal of Applied Psychology, Vol. 88 No. 5, pp. 879-903.

Preacher, K.J., Zyphur, M.J. and Zhang, Z. (2010), “A general multilevel SEM framework for assessing multilevel mediation”, Psychological Methods, Vol. 15 No. 3, pp. 209-233.

Raisch, S. and Birkinshaw, J. (2008), “Organizational ambidexterity: antecedents, outcomes, and moderators", Journal of Management, Vol. 34 No. 3, pp. $375-409$.

Reitzig, M. and Maciejovsky, B. (2015), "Corporate hierarchy and vertical information flow inside the firm - a behavioral view", Strategic Management Journal, Vol. 36 No. 13, pp. 1979-1999.

Rogan, M. and Mors, M.L. (2014), “A network perspective on individual-level 59 60 
ambidexterity in organizations", Organization Science, Vol. 25 No. 6, pp. $1860-1877$.

Shiffrin, R.M. and Schneider, W. (1977), "Controlled and automatic human information processing: II. Perceptual learning, automatic attending and a general theory", Psychological Review, Vol. 84 No. 2, pp. 127-190.

Simon, H.A. (1978), "Information-processing theory of human problem solving", in Estes, W.K. (Ed.), Handbook of Learning \& Cognitive Processes: V. Human Information, Lawrence Erlbaum, Oxford, England, pp. 271-295.

Srivastava, A., Bartol, K.M. and Locke, E.A. (2006), "Empowering leadership in management teams: effects on knowledge sharing, efficacy, and performance", Academy of Management Journal, Vol. 49 No. 6, pp. 1239-1251.

Stewart, J. (1999), Bridges not Walls: A Book about Interpersonal Communication, $7^{\text {th }}$ ed., McGraw-Hill, New York, NY.

Stewart, J., Zediker, K. and Black, L. (2004), "Relationships among philosophies of dialogue", in Anderson, R., Baxter, L.A. and Cissna, K.N. (Eds.), Dialogue: Theorizing Difference in Communication Studies, Sage, Thousand Oaks, CA, pp. 21-38.

Tabachnick, B.G. and Fidell, L.S. (1996), Using Multivariate Statistics, $3^{\text {rd }}$ ed., New York, NY, Harper Collins College. 
Trevor-Roberts, E., Ashkanasy, N.M. and Kennedy, J.C. (2003), “The egalitarian leader: a comparison of leadership in Australia and New Zealand", Asia Pacific Journal of Management, Vol. 20 No. 4, pp. 517-540.

Tsai, W. (2001), "Knowledge transfer in intraorganizational networks: effects of network position and absorptive capacity on business unit innovation and performance", Academy of Management Journal, Vol. 44 No. 5, pp. 996-1004.

Tushman, M. (1977), "Special boundary roles in the innovation process", Administrative Science Quarterly, Vol. 22 No. 4, pp. 587-605.

Van Den Bosch, F.A., Volberda, H.W. and De Boer, M. (1999), "Coevolution of firm absorptive capacity and knowledge environment: organizational forms and combinative capabilities”, Organization Science, Vol. 10 No. 5, pp. 551-568.

van Doorn, S., Heyden, M.L. and Volberda, H.W. (2017), “Enhancing entrepreneurial orientation in dynamic environments: the interplay between top management team advice-seeking and absorptive capacity", Long Range Planning, Vol. 50 No. 2, pp. 134-144.

Vera, D. and Crossan, M. (2004), "Strategic leadership and organizational learning”, Academy of Management Review, Vol. 29 No. 2, pp. 222-240.

Wang, H., Law, K.S., Hackett, R.D., Wang, D. and Chen, Z.X. (2005), "Leader-member exchange as a mediator of the relationship between 
transformational leadership and followers' performance and organizational citizenship behavior", Academy of Management Journal, Vol. 48 No. 3, pp. 420-432.

Wang, S. and Noe, R.A. (2010), "Knowledge sharing: a review and directions for future research", Human Resource Management Review, Vol. 20 No. 2, pp. $115-131$.

Wei, Z., Yang, D., Sun, B. and Gu, M. (2014), "The fit between technological innovation and business model design for firm growth: evidence from China", R\&D Management, Vol. 44 No. 3, pp. 288-305.

Zaltman, G., Duncan, R. and Holbek, J. (1973), Innovations and Organizations, Wiley, London, UK.

Zollo, M. and Winter, S.G. (2002), "Deliberate learning and the evolution of dynamic capabilities”, Organization Science, Vol. 13 No. 3, pp. 339-351. 


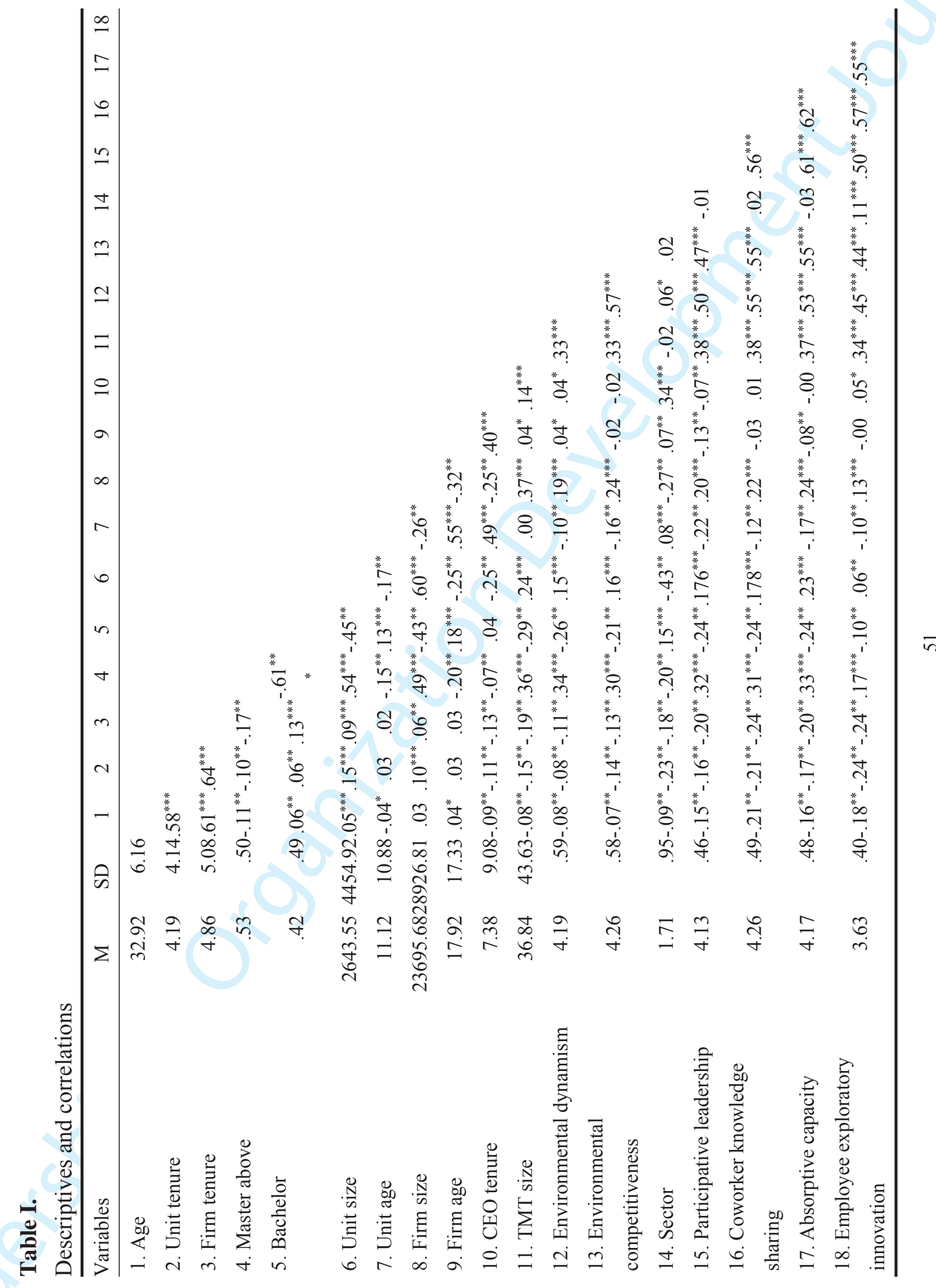

$m$
0
40
$i n$
0
0
0
0 


\section{Table II.}

Comparisons of measurement models

\begin{tabular}{cccccccccc}
\hline Model & No. of factors & $\chi^{2}$ & $d f$ & $\Delta \chi^{2}$ & $\Delta d f$ & RMSEA & CFI & GFI & TLI \\
\hline Baseline & Four $^{\mathrm{a}}$ & 813.08 & 293 & - & - & .08 & .94 & .90 & .93 \\
1 & Three $^{\mathrm{b}}$ & 1151.71 & 294 & $338.63^{* * *}$ & 1 & .10 & .93 & .86 & .92 \\
2 & Three $^{\mathrm{c}}$ & 1231.14 & 294 & $418.06^{* * *}$ & 1 & .11 & .93 & .86 & .92 \\
3 & Three $^{\mathrm{d}}$ & 1218.68 & 294 & $405.6^{* * *}$ & 1 & .11 & .93 & .86 & .92 \\
4 & Three $^{\mathrm{e}}$ & 1120.71 & 294 & $307.63^{* * *}$ & 1 & .11 & .93 & .86 & .92 \\
5 & Three $^{\mathrm{f}}$ & 1210.60 & 294 & $397.52^{* * *}$ & 1 & .11 & .93 & .86 & .92 \\
6 & Three $^{\mathrm{g}}$ & 1191.85 & 294 & $378.77^{* * *}$ & 1 & .11 & .93 & .86 & .92 \\
7 & Two $^{\mathrm{h}}$ & 1949.55 & 296 & $1136.47^{* * *}$ & 3 & .12 & .82 & .75 & .81 \\
8 & Two $^{\mathrm{i}}$ & 1937.09 & 296 & $1124.01^{* * *}$ & 3 & .12 & .82 & .75 & .82 \\
9 & Two $^{\mathrm{j}}$ & 1951.48 & 296 & $1138.4^{* * *}$ & 3 & .12 & .82 & .75 & .81 \\
10 & Two $^{\mathrm{k}}$ & 1929.99 & 296 & $1116.91^{* * *}$ & 3 & .12 & .82 & .75 & .82 \\
11 & One $^{1}$ & 2956.18 & 299 & $2143.1^{* * *}$ & 6 & .15 & .72 & .65 & .71 \\
\hline
\end{tabular}

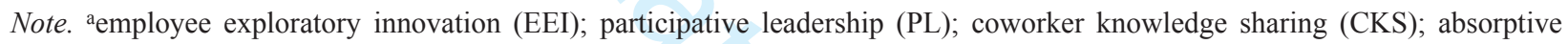

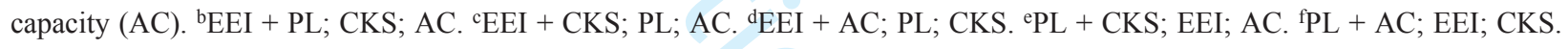
${ }^{\mathrm{g}} \mathrm{CKS}+\mathrm{AC}$; EEI; PL. ${ }^{\mathrm{h} E E I}+\mathrm{PL}+\mathrm{CKS} ; \mathrm{AC} .{ }^{\mathrm{i}} \mathrm{EEI}+\mathrm{PL}+\mathrm{AC} ; \mathrm{CKS} .{ }^{\mathrm{j} E E I}+\mathrm{CKS}+\mathrm{AC} ; \mathrm{PL} .{ }^{\mathrm{k} P L}+\mathrm{CKS}+\mathrm{AC} ; \mathrm{EEI} .{ }^{\mathrm{l} E E I}+\mathrm{PL}+$ $\mathrm{CKS}+\mathrm{AC}$.

${ }^{*} p<.05,{ }^{* *} p<.01,{ }^{* * *} p<.001$. 
Table III.

Results of the mediation model ${ }^{\mathrm{a}}$

\begin{tabular}{|c|c|c|c|}
\hline \multirow[t]{2}{*}{ Part (unstandardized estimates) } & \multirow[t]{2}{*}{ Estimate } & \multicolumn{2}{|c|}{ Normal distribution } \\
\hline & & $\operatorname{LLCI}^{\mathrm{d}}$ & $\mathrm{ULCl}^{\mathrm{d}}$ \\
\hline Participative leadership $\rightarrow$ coworker knowledge sharing & $.66^{* * *}$ & .51 & .81 \\
\hline Participative leadership $\rightarrow$ absorptive capacity & $.39^{* * *}$ & .31 & .47 \\
\hline Coworker knowledge sharing $\rightarrow$ absorptive capacity & $.56^{* * *}$ & .47 & .65 \\
\hline Coworker knowledge sharing $\rightarrow$ employee exploratory innovation & $.18^{* * *}$ & .08 & .28 \\
\hline $\begin{array}{l}\text { A: Direct effect } \\
\text { Participative leadership } \rightarrow \text { employee exploratory innovation }\end{array}$ & $.13^{* * *}$ & .08 & .18 \\
\hline Absorptive capacity $\rightarrow$ employee exploratory innovation & $.10^{*}$ & .02 & .18 \\
\hline Firm size $(\log )^{\mathrm{b}} \rightarrow$ employee exploratory innovation & -.01 & -.03 & .01 \\
\hline Firm age $\rightarrow$ employee exploratory innovation & -.001 & -.004 & .002 \\
\hline Unit size $\rightarrow$ employee exploratory innovation & .00 & .00 & .00 \\
\hline Unit age $\rightarrow$ employee exploratory innovation & .00 & -.01 & .01 \\
\hline Environmental dynamism $\rightarrow$ employee exploratory innovation & -.04 & -.15 & .07 \\
\hline Environmental competitiveness $\rightarrow$ employee exploratory innovation & $.12^{*}$ & .03 & .21 \\
\hline High technology $\rightarrow$ employee exploratory innovation & .17 & .01 & .33 \\
\hline Low technology ${ }^{\mathrm{b}} \rightarrow$ employee exploratory innovation & .17 & .01 & .33 \\
\hline Age $\rightarrow$ employee exploratory innovation & $.008^{*}$ & .003 & .013 \\
\hline Firm tenure $\rightarrow$ employee exploratory innovation & $-.03^{* *}$ & -.05 & -.01 \\
\hline Unit tenure $\rightarrow$ exploratory innovation & .01 & -.02 & .03 \\
\hline Master above $\rightarrow$ employee exploratory innovation & -.02 & -.20 & .16 \\
\hline Bachelor $\rightarrow$ employee exploratory innovation & .07 & -.12 & .26 \\
\hline TMT size $^{\mathrm{b}} \rightarrow$ employee exploratory innovation & $.002^{* *}$ & .001 & .003 \\
\hline CEO tenure ${ }^{b} \rightarrow$ employee exploratory innovation & .003 & -.003 & .009 \\
\hline B: Indirect effect & $.21^{* * *}$ & .12 & .30 \\
\hline $\begin{array}{l}\text { Participative leadership } \rightarrow \text { coworker knowledge sharing } \rightarrow \text { employee exploratory } \\
\text { innovation }\end{array}$ & & .05 & .19 \\
\hline $\begin{array}{l}\text { Participative leadership } \rightarrow \text { absorptive capacity } \rightarrow \text { employee exploratory } \\
\text { innovation }\end{array}$ & $.05^{*}$ & .02 & .08 \\
\hline $\begin{array}{l}\text { Participative leadership } \rightarrow \text { coworker knowledge sharing } \rightarrow \text { absorptive capacity } \rightarrow \\
\text { employee exploratory innovation }\end{array}$ & $.04^{*}$ & .01 & .07 \\
\hline C: Total effect & $.34^{* * *}$ & .25 & .43 \\
\hline
\end{tabular}

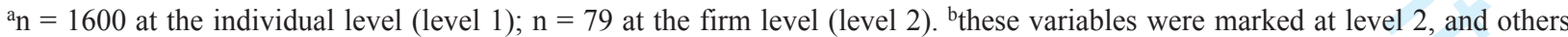
were at level $1 .{ }^{\mathrm{c}^{*}} p<.05,{ }^{* *} p<.01,{ }^{* * *} p<.001 .{ }^{\mathrm{d}} \mathrm{CI}=$ confidence interval; LLCI $=$ lower level of the $95 \%$ confidence interval; $\mathrm{ULCI}=$ upper level of the $95 \%$ confidence interval. 
Table IV.

Results of the mediation model ${ }^{\mathrm{a}}$

\begin{tabular}{|c|c|c|c|}
\hline \multirow{2}{*}{ Part (unstandardized estimates) } & \multirow[t]{2}{*}{ Estimate } & \multicolumn{2}{|c|}{ Monte Carlo Simulation } \\
\hline & & LLCI $^{\mathrm{d}}$ & $\mathrm{ULCI}^{\mathrm{d}}$ \\
\hline Participative leadership $\rightarrow$ coworker knowledge sharing & $.66^{* * *}$ & .51 & .88 \\
\hline Participative leadership $\rightarrow$ absorptive capacity & $.39^{* * *}$ & .31 & .51 \\
\hline Coworker knowledge sharing $\rightarrow$ absorptive capacity & $.56^{* * *}$ & .47 & .71 \\
\hline Coworker knowledge sharing $\rightarrow$ employee exploratory innovation & $.18^{* * *}$ & .08 & .30 \\
\hline $\begin{array}{l}\text { A: Direct effect } \\
\text { Participative leadership } \rightarrow \text { employee exploratory innovation }\end{array}$ & $.13^{* * *}$ & .08 & .20 \\
\hline Absorptive capacity $\rightarrow$ employee exploratory innovation & $.10^{*}$ & .02 & .20 \\
\hline Firm size $(\log )^{b} \rightarrow$ employee exploratory innovation & -.01 & -.04 & .01 \\
\hline Firm age $^{\mathrm{b}} \rightarrow$ employee exploratory innovation & -.001 & -.01 & .002 \\
\hline Unit size $\rightarrow$ employee exploratory innovation & .00 & .00 & .00 \\
\hline Unit age $\rightarrow$ employee exploratory innovation & .00 & -.01 & .01 \\
\hline Environmental dynamism $\rightarrow$ employee exploratory innovation & -.04 & -.16 & .07 \\
\hline Environmental competitiveness $\rightarrow$ employee exploratory innovation & $.12^{*}$ & .03 & .23 \\
\hline High technology $\mathrm{y}^{\mathrm{b}} \rightarrow$ employee exploratory innovation & .17 & .01 & .35 \\
\hline Low technology $\mathrm{y}^{\mathrm{b}} \rightarrow$ employee exploratory innovation & .17 & .01 & .35 \\
\hline Age $\rightarrow$ employee exploratory innovation & $.008^{*}$ & .003 & .02 \\
\hline Firm tenure $\rightarrow$ employee exploratory innovation & $-.03^{* *}$ & -.06 & -.01 \\
\hline Unit tenure $\rightarrow$ exploratory innovation & .01 & -.02 & .04 \\
\hline Master above $\rightarrow$ employee exploratory innovation & -.02 & -.21 & .16 \\
\hline Bachelor $\rightarrow$ employee exploratory innovation & .07 & -.12 & .27 \\
\hline TMT size ${ }^{\mathrm{b}} \rightarrow$ employee exploratory innovation & $.002^{* *}$ & .001 & .004 \\
\hline CEO tenure ${ }^{b} \rightarrow$ employee exploratory innovation & .003 & -.003 & .01 \\
\hline$B:$ Indirect effect & $21^{* * *}$ & .12 & .33 \\
\hline $\begin{array}{l}\text { Participative leadership } \rightarrow \text { coworker knowledge sharing } \rightarrow \text { employee exploratory } \\
\text { innovation }\end{array}$ & $.12^{* *}$ & .05 & .21 \\
\hline $\begin{array}{l}\text { Participative leadership } \rightarrow \text { absorptive capacity } \rightarrow \text { employee exploratory } \\
\text { innovation }\end{array}$ & $.05^{*}$ & .02 & .09 \\
\hline $\begin{array}{l}\text { Participative leadership } \rightarrow \text { coworker knowledge sharing } \rightarrow \text { absorptive capacity } \rightarrow \\
\text { employee exploratory innovation }\end{array}$ & $.04^{*}$ & .01 & .08 \\
\hline C: Total effect & $.34^{* * *}$ & .25 & .47 \\
\hline
\end{tabular}

${ }^{a} \mathrm{n}=1600$ at the individual level (level 1); $\mathrm{n}=79$ at the firm level (level 2). b these variables were marked at level 2, and others were at level $1 .{ }^{\mathrm{c}^{*}} p<.05,{ }^{* *} p<.01,{ }^{* * *} p<.001 .{ }^{\mathrm{d}} \mathrm{CI}=$ confidence interval; LLCI $=$ lower level of the $95 \%$ confidence interval; ULCI $=$ upper level of the $95 \%$ confidence interval. ${ }^{\mathrm{e}} 50000$ times. 




Figure 1.

Research framework 
Appendix. Survey items

\section{Employee exploratory innovation}

(building on Mom et al., 2009, 1 = very small extent to 7 = very large extent)

- Searching for new possibilities with respect to products/services, processes, or markets.

- Evaluating diverse options with respect to products/services, processes, or markets.

- Focusing on strong renewal of products/services or processes.

- Activities of which the associated yields or costs are currently unclear.

- Activities requiring quite some adaptability of your employee.

- Activities requiring your employee to learn new skills or knowledge.

- Activities that are not (yet) clearly existing company policy.

\section{Participative leadership}

(building on Arnold et al., 2000, 1 = strongly disagree to 7 = strongly agree)

- Encourages work group members to express ideas/suggestions.

- Listens to my work group's ideas and suggestions.

- Uses my work group's suggestions to make decisions that affect us.

- Gives all work group members a chance to voice their opinions.

- Considers my work group's ideas when he/she disagrees with them.

- Makes decisions that are based only on his/her own ideas.

\section{Coworker knowledge sharing}

(building on Kim and Yun, 2015, 1 = strongly disagree to $7=$ strongly agree)

- Coworkers in our team shares their special knowledge and expertise with one another.

- If coworkers in our team have some special knowledge about how to perform the task, they are likely to tell one another about it.

- Coworkers in our team exchange information, knowledge, and sharing of skills with one another.

- Coworkers in our team freely provide one another with hard-to-find knowledge or specialized skills.

- Coworkers in our team help one another in developing relevant strategies.

- Coworkers in our team share lot of information with one another.

- Coworkers in our team offer lots of suggestions to one another.

\section{Absorptive capacity}

(building on Chang et al., 2012, 1 = strongly disagree to 7 = strongly agree)

- Have the ability to acquire new knowledge from the company to achieve targets.

- Have a vision of what the unit is trying to achieve through the transfer of knowledge from the company.

- Have the technical competency to absorb the knowledge from the company.

- Have the necessary skills to implement the practices from the company. 
- Have the ability to convert knowledge or the practices from the company.

- Have the ability to exploit new knowledge or practices from the company.

\section{Environmental dynamism}

(building on Jansen et al., 2006, 1 = strongly disagree to 7 = strongly agree)

- Environmental changes in our local market are intense.

- Our clients regularly ask for new products and services.

- In our local market, changes are taking place continuously.

- In a year, nothing has changed in our market.

- In our market, the volumes of products and services to be delivered change fast and often.

\section{Environmental competitiveness}

(building on Jansen et al., 2006, 1 = strongly disagree to 7 = strongly agree)

- Competition in our local market is intense.

- Our organizational unit has relatively strong competitors.

- Competition in our local market is extremely high.

- Price competition is a hallmark of our local market.

\section{Social desirability}

(building on Hays et al., 1989, 1 = definitely true to 7 = definitely false)

- I am always courteous even to people who are disagreeable.

- There have been occasions when I took advantage of someone.

- I sometimes try to get even rather than forgive and forget.

- I sometimes feel resentful when I don't get my way.

- No matter who I'm talking to, I'm always a good listener. 